\author{
Sajida \\ Departement of Public Policy and Management, Faculty of Social and Political Sciences, Universitas Gadjah Mada \\ (email: sajida@mail.ugm.ac.id)
}

Submitted: 10 October 2021, Revised: 6 December 2021, Accepted: 15 December 2021

Sajida is currently completing her master's degree in Management and Public Policy, University of Gadjah Mada. She graduated from Government Studies, The Faculty of Social and Political Sciences, University of Brawijaya. She works as a research assistant on several projects, including partnering with the government in the preparation of policy documents such as road maps, policy notes, and others. Sajida has an interest in research and writing in the areas of policy, education, public services, and literature reviews in social fields.

Policy \& Governance Review ISSN 2580-4820

Vol. 6, Issue 1, pp. 17-39

DOI: https://doi.org/10.30589/pgr. v6i1.391

\title{
Mapping Trends of Literature in Energy Policy in Indonesia: A Bibliometric Analysis
}

\begin{abstract}
Energy policy recently became an issue that has been highlighted by various parties, including academics in Indonesia. This coincides with the signs of the climate crisis, and the environmental damage that is affected by energy management. Although, there have been many studies discussing it, so far, there has been no research showing the direction of energy policy in Indonesia. Thus, this paper aims to map the trends in the literature. Bibliometric analysis is used to map topics raised from various research article by looking at the most common keywords, and identifying the most cited and productive sources. Per the results, the discussion of renewable energy and related topics became the dominant issue in the mapping of this main topic from 2003 to 2021. Then Energy Policy Journal the most cited reference, and the Iop Conference Series: Earth and Environmental Science became the most productive source. The results of this study indicate indirectly, how far Indonesia's energy policy has developed periodically. Including how Indonesia amid various countries has been campaigning for renewable energy that pays attention to the environment. Besides, this research also provides future research agendas for others to examine energy policy in Indonesia from various perspectives that have not been studied previously.
\end{abstract}

\section{Keywords}

energy policy; renewable energy; Indonesia; bibliometric analysis

\section{Introduction}

The growth in the global population has also increased the demand for energy. Energy is an absolute necessity for the country's economic development, although so far fossil fuels or coal are still the main fuel and have a negative impact on the environment (Mihajlovic \& Trajkovic, 2018). Therefore, an energy policy is needed to regulate and manage energy use so that it can still be used for survival, but attention can also be paid to environmental impacts. Energy policy involves interventions in the coal, electricity, oil and gas, and nuclear and renewable energy sectors, and activities aimed at increasing the efficiency of 
energy supply and consumption (Prontera, 2009). Thus, energy policy has become an important topic that has recently been promoted by various parties, including academics. This is also because energy issues are very important for the country to maintain sustainable economic development. (Özcan, 2013).

Looking further, the energy policy issues highlighted by academics in various countries in the last five years also show a certain pattern. Searching in Scopus with the keyword energy policy and sorting by most cited articles reveals that academics are more interested in renewable energy policy topics (Aized et al., 2018; Hache \& Palle, 2019; Polzin et al., 2019; Schmidt \& Sewerin, 2019; Sinha et al., 2018), along with the resources that become raw materials of it, such as biogas, diesel, biomass, wind (Ardo et al., 2018; Banja et al., 2019; Best \& Burke, 2018; Scarlat et al., 2018), economic calculation of the use of renewable energy (Bulavskaya \& Reynès, 2018; Purkus et al., 2018; Szinai et al., 2020; Ziegler et al., 2019) to the dynamics of energy policy formulation (Apergis \& Gangopadhyay, 2020; Ebrahimigharehbaghi et al., 2019; Pereira et al., 2018; Rabe et al., 2019; Robertson Munro \& Cairney, 2020), or energy security (Karatayev \& Hall, 2020; Nyga-Lukaszewska et al., 2020), and the political process that occurs in it (Li \& Pye, 2018; Pegels et al., 2018; Stokes \& Breetz, 2018).

Energy policy has become a widely debated issue, because of the real impact of climate change that developed countries are experiencing. In Europe, the increase in temperature becomes a tangible effect, especially in summer (Droulia \& Charalampopoulos, 2021; Pasqui \& Di Giuseppe, 2019). In the United States, New Jersey seems an unlikely place to measure climate change, but it turned out to be one of the fastest warming states in the country. The average temperature has risen to nearly 2 degrees Celsius, a level that not been seen since 1895 (Mufson et al., 2019). On the other hand, since 2005, the contribution of developed countries to global temperature increases, sea ice loss and upper ocean warming is about 60 $80 \%$, while that of developing countries is 20 $40 \%$ (Malhi et al., 2021). In reality, however, this influence on environmental degradation happens in nearly every area of the world, including Indonesia. The flooding that happened in Jakarta In January 2020 is a sign of it. BMKG stated that the rainfall intensity in Jakarta was higher than it had been in 150 years (Ramadhan, 2020). Meanwhile, previously the long dry season occurred which caused NTT to become the driest area in Indonesia because it did not rain for 259 days sequentially (CNN Indonesia, 2019).

Pulling back on the context in Indonesia, it also joined The 2021 United Nations Climate Change Conference (COP26) as a step to commit to preventing the climate crisis (Cabinet Secretariat of The Republic of Indonesia, 2021). However, this is quite contradictory because of the fact that Indonesia has been one of the biggest coal producers and exporters globally since 2019, even though the number of exports has decreased (Febriadi et al., 2018; International Energy Agency (IEA), 2020). While previously it was also mentioned that the use of coal has a negative correlation with the environment. It is interesting from the context of the reality that occurred, this then raises the question of how energy policy research in Indonesia develops globally.

Research that discusses energy policy in Indonesia so far is quite multidimensional and looks at it from various sides. In general, the topics that are widely discussed from the theme of energy policy in Indonesia are also not much different from the topic of energy policy at the global level. Starting from how the economic point of view considers the use of renewable energy (Aydoğan \& Vardar, 2020; Chiou-Wei et al., 2008; Masih \& Masih, 1996), biofuel management policy (Putrasari et al., 2016; Sorda et al., 2010), energy security (Kumar, 2016; Mujiyanto \& Tiess, 2013) or about electricity consumption (Heryana et al., 
2018; Lee et al., 2020; Tanoto \& Praptiningsih, 2013). However, no research has been conducted to date that maps how the literature in Indonesian energy policy develops.

Therefore, this research will attempt to understand the development of issues in the topic of energy policy in Indonesia raised by scholars globally. Similar research has been carried out before, starting from energy policy in the European Union (Annibaldi et al., 2020), research on energy in general in Nigeria (Adedayo et al., 2021), as well as research on energy, economics and policy globally over the last decade (Muhtar et al., 2021). Using a similar method, bibliometric analysis, this study aims to map the literature on this topic by looking at keywords that are widely used in various research articles published in recent years, as well as literature sources that are widely used as references and are productive in promoting the topic of energy policy in Indonesia. Eventually it will appear as an illustration of the extent to which energy policy in Indonesia has developed, as well as the various scopes of issues that are submerged and need to be raised by scholars to be able to encourage decision-making and better energy management.

\section{Methods}

The purpose of this research is to map the literature on this topic by looking at the keywords widely used in various article published in recent years. Bibliometrics is a method that has been widely utilized in the academic community to thoroughly map knowledge. Bibliometric analysis methods rely on research references to create statistical models for the flow of scientific connections between them (Tsay \& Shu, 2011). As longitudinal studies of scientific interest contribute to determining areas of research that are developing or retreating, bibliometric data can serve as a point of reference for science and technology issues (Nicula et al., 2013). According (Lotka, 1926) The term "bibliometric analysis" refers to a "method for measuring researcher productivity" (Brika et al., 2021). Meanwhile, bibliometric mapping provides a unique perspective in this field when compared to traditional methods; each study can examine the relationship between current research and research analysis. As a result, bibliometric research enables participants to participate in a variety of tasks, thereby minimizing bias and research choices (Mulet-Forteza et al., 2019). The research preparation was carried out in numerous stages that followed the research utilizing the bibliometric approach that had previously been carried out (Brika et al., 2021; Cao et al., 2021; Khanra et al., 2021).

Most bibliometric research focuses on one concern and is not limited to specific territory in order to provide broad and detailed knowledge, as has been done in recent years (Apriliyanti \& Alon, 2017; Khanra et al., 2021; Ye \& Li, 2020; Zupic \& Čater, 2015). However, this study follows what has been done by previous researchers who conducted research at one locus with an underlying empirical background (Adedayo et al., 2021; Akbar, 2020; Annibaldi et al., 2020; Bullock \& Lawler, 2015; Chen et al., 2018).

The first stage of this research is identifying a database that supports the research goals; therefore, the source of the data must be reliable and appropriate in order to complete the analysis and make the right decision (Khan et al., 2020; Rueda et al., 2007). The material in this study was acquired via database searches on the Scopus platform, which provides information on scientific journals, scientific papers, books, events, and other items. Scopus is one of the major databases that provides trustworthy and frequently updated indexing of journal papers, which is consistent with the study's aims (Cao et al., 2021; Gümüş et al., 2020). The selection of data collection at Scopus also takes into account that this study looks at global trends in energy policy in Indonesia. Then, inclusion criteria are set in 
order to locate the appropriate scientific work to be evaluated, and literature that is unrelated to the topic of discussion is excluded, as has been done by other researchers (Cao et al., 2021). In this research, energy is used as the first keyword for object analysis. Then, for policy-related keywords, we make a list of keywords that are similar in terms to policies, namely policy/policies, decisionmaking, law, and regulation as the output of a policy. We also add Government as a policy-related keyword to broaden the search and perspective as a policymaker. Then, we also input the keyword Indonesia to focus the scope of the literature locus to be analyzed.

These keywords are then linked with Boolean operators (AND, OR). After that, the keywords are arranged as follows;

TITLE-ABS-KEY(energy AND (policy OR policies OR "decision making" OR law OR regulation OR government) AND Indonesia). The second stage was the literature search, which was carried out after the preparation of specific keywords and criteria, and at the same time, the screening of document types was carried out (Cao et al., 2021). The search string found a total of 1648 articles. Then, to find articles that discuss indepth energy policy in Indonesia, we also limit the research to English-only articles that have been final presses, containing pre-determined related keywords. The author also selected only articles that were openly accessible. However, to maintain the wealth of literary sources, the author did not the period of publication, publisher, country or subject area, variety or type of publication, affiliation, or other criteria. This was done to enrich the literature mapping picture, because research in the form of articles on this topic is very limited, and restrictions on the period of publication, publisher, country or subject area, variety or type of publication will cause bias. The application of inclusion and exclusion of these articles resulted in several findings from 154 records from conference papers, articles, reviews, and book chapters. Furthermore, screening of titles and abstracts was also carried out to ensure that the literature found addresses the topics raised. As a result, there were 152 pieces of literature that were included in the material for analysis.

The third stage is bibliometric analysis. In this paper, we use VOS-Viewer 1.6.17 as a tool for visualizing mapping in the literature. According to (Van Eck \& Waltman, 2013), VoSviewer can be used to build a network of scientific papers, journals, researchers, research organizations, countries, keywords or terms. Co-authors, cooccurrences, citations, bibliographic coupling, and co-citation links can connect items in these networks (Rialti et al., 2019). VOSviewer allows for the analysis of keywords in documents in the Scopus database, with one of the goals being to highlight the links between the aforementioned keywords (Dinu \& Constantin, 2020). VOSviewer generates a map where the distance between items can be interpreted as an indication of term relevance. The closer the terms are to each other, the more strongly they are associated with each other (Rialti et al., 2019). In some bibliometric studies, researchers combined this method with other methods like systematic literature review, content analysis, or narrative reviews to describe each finding in detail or provide an in-depth analysis (Cheng \& Edwards, 2016; Rialti et al., 2019). However, here the researcher provides an interpretation and a brief discussion of the results by only using bibliometric analysis. The researcher also provides an interpretation of clustering as done in other similar projects (Khanra et al., 2021). Then, following others authors` lead (Apriliyanti \& Alon, 2017; Reddy et al., 2018), the researcher also suggested some future research agendas that can be conducted by other researchers from the clustering compiled based on the findings report.

Bibliometric analysis can be developed using a variety of techniques, including citation, 
co-citation, and bibliometric coupling. The method chosen is determined by the investigation's goal (Bretas \& Alon, 2021). According to the purpose of this research, that is, to map the most frequently occurring keywords and the most cited and productive publication sources, and to produce articles on related topics, this study will use bibliographic coupling to determine the intellectual structure of the current literature, and because of its ability to describe the flow of wealth of theoretical and theoretical approaches (Zupic \& Čater, 2015). Bibliographic coupling was also chosen because, when compared to the other two approaches, citation and co-citation, it represents literature mapping more accurately (Boyack \& Klavans, 2010). Additionally, keyword analysis is performed to determine the evolution of issues or topics raised in the discussion of energy policy in Indonesia. This kind of analysis is important because synthesizing the results of previous research is one of the most important tasks in advancing a specific research direction (Zupic \& Čater, 2015), and can be used as material for analysis of the development focus of energy policy in Indonesia.

Table 1.

\section{Research Method}

\begin{tabular}{cl}
\hline Step & \multicolumn{1}{c}{ Details } \\
\hline Identification & - Define database. \\
& - Specifying search string. \\
& - Determine inclusion and \\
& exclusion criteria. \\
$\begin{array}{c}\text { Searching and } \\
\text { Screening } \\
\text { Process }\end{array}$ & $\begin{array}{c}\text { The first search found } 1648 \\
\text { records. }\end{array}$ \\
& The application of the first \\
& screening resulted in 154 \\
& records. \\
& The application of the second \\
& screening resulted in 152 \\
& records. \\
Bibliometric & - Literature mapping identified \\
Analysis & by VoS Viewer 1.6.17. \\
& - Components of analysis: Most \\
& Cited and Productive Sources, \\
& Highest Occurrence Keyword. \\
Interpretation & - Discuss the results of the \\
& literature mapping. \\
\hline
\end{tabular}

Source : Processed by Author

\section{Data Findings}

\section{a) Literature Development}

A total of 152 papers from Scopus which were included from the previous screening process were then used for bibliometric analysis. First, looking at the trajectory of the year, the first literature reviewing on energy policy in Indonesia began in 2003 which discussed the importance of groups that can support the policy to introduce natural gas into the fuel mix (Van Groenendaal, 2003). During the next 11 years until 2014, there were only five publications (including the first publication) that discussed energy policy. Except the article written by (Van Groenendaal, 2003) , the focus of the discussion raised in that period included various topics. They began with a discussion about irrigation management in the subak system in Bali and comparing it with energy management in other developing countries, to be a lesson for developed countries to achieve energy sustainability (Ramaswami et al., 2007), then analysis about the status of Indonesia in the Clean Development Mechanism (CDM) non-sink projects (Jung, 2006). There is also interesting research from Hartono \& Resosudarmo (2008) which calculates the economic impact of energy policies aimed at reducing and increasing the efficiency of energy use through various scenarios, as well as an in-depth review of the importance of multi-level governance issues to support renewable energy (Marquardt, 2014). Until 2015 the topic of energy policy began to be brought up again and reached its peak in 2018-2019 with an increase in publications of more than $100 \%$ compared to 2017.

Furthermore, looking at the cluster of types of literature documents discussing energy policy in Indonesia, it is strongly dominated by conference papers or proceedings with $74.3 \%$ of them $(n=113)$. Publications in the form of articles have a share of $22.4 \%(n=34)$, and studies that produce reviews include four records. It is interesting that these four publications discuss the intersecting big themes, namely sustainability 
Figure 1.

Number of Published Energy Policy Literature in Indonesia from 2003-2021

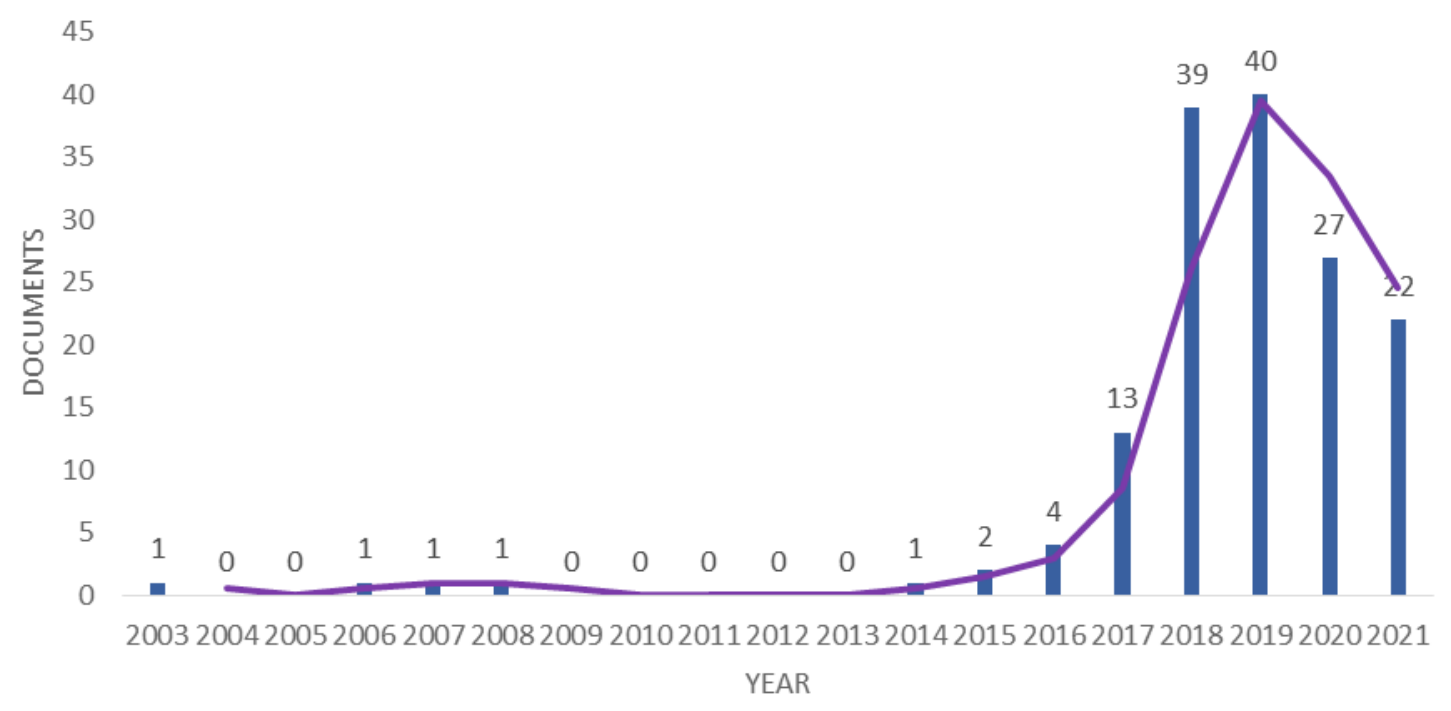

Source: Processed by Author

Figure 2.

Documents by Type of Energy Policy

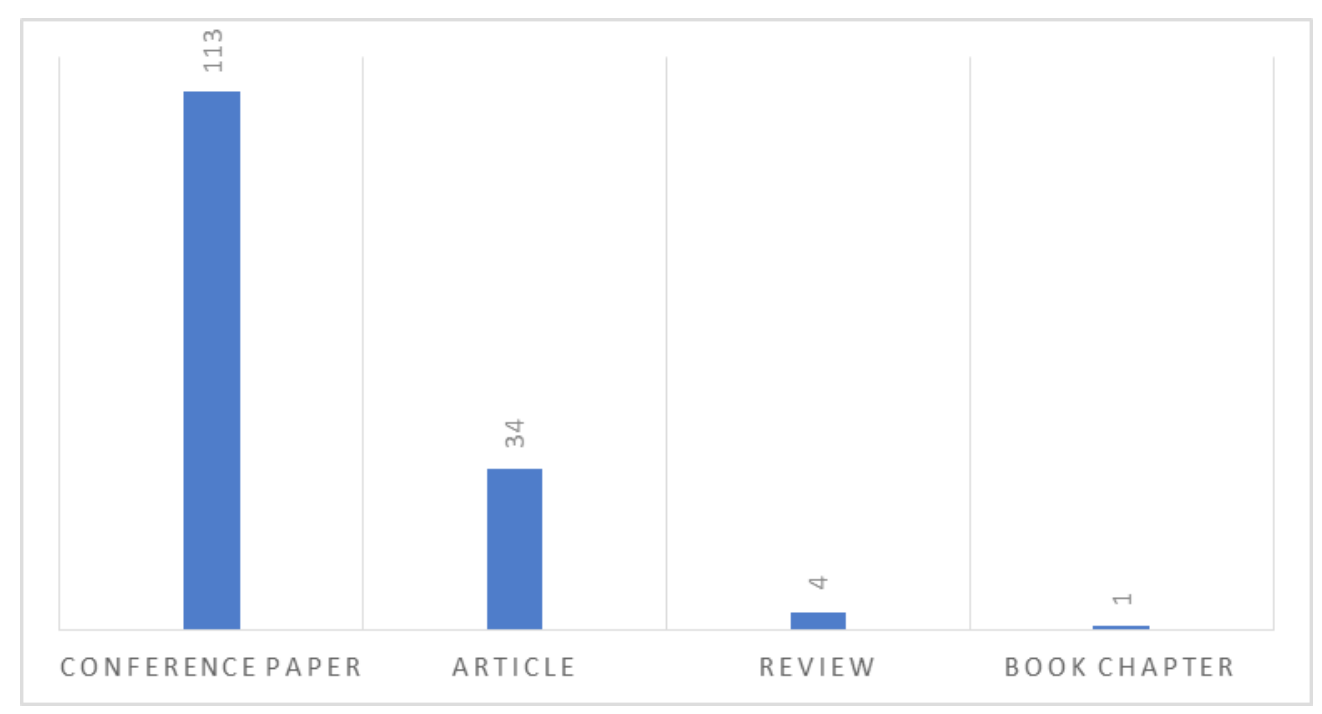

Source: Processed by Author

(Ramaswami et al., 2007) and renewable energy from different perspectives (Silalahi et al., 2020; Vakulchuk et al., 2020; Yudha \& Tjahjono, 2019). Meanwhile, for the book chapter there is only onepublication that raises this topic, where this paper discusses nuclear technology which can be an energy option that can be a solution to overcome the increase in global $\mathrm{CO} 2$ emissions. (Suharta et al., 2017).
Next, looking at the various subject areas of energy policy, the most published literature from the subject area, environmental science, earth and planet, and energy is the subject area group with the most published articles. A total of 232 pieces of literature are included on these three subjects. Regarding the classification, the determination uses the ASJC (All Science Journal Classification) scheme which is carried out by the 
Figure 3.

Subject Area of Energy Policy

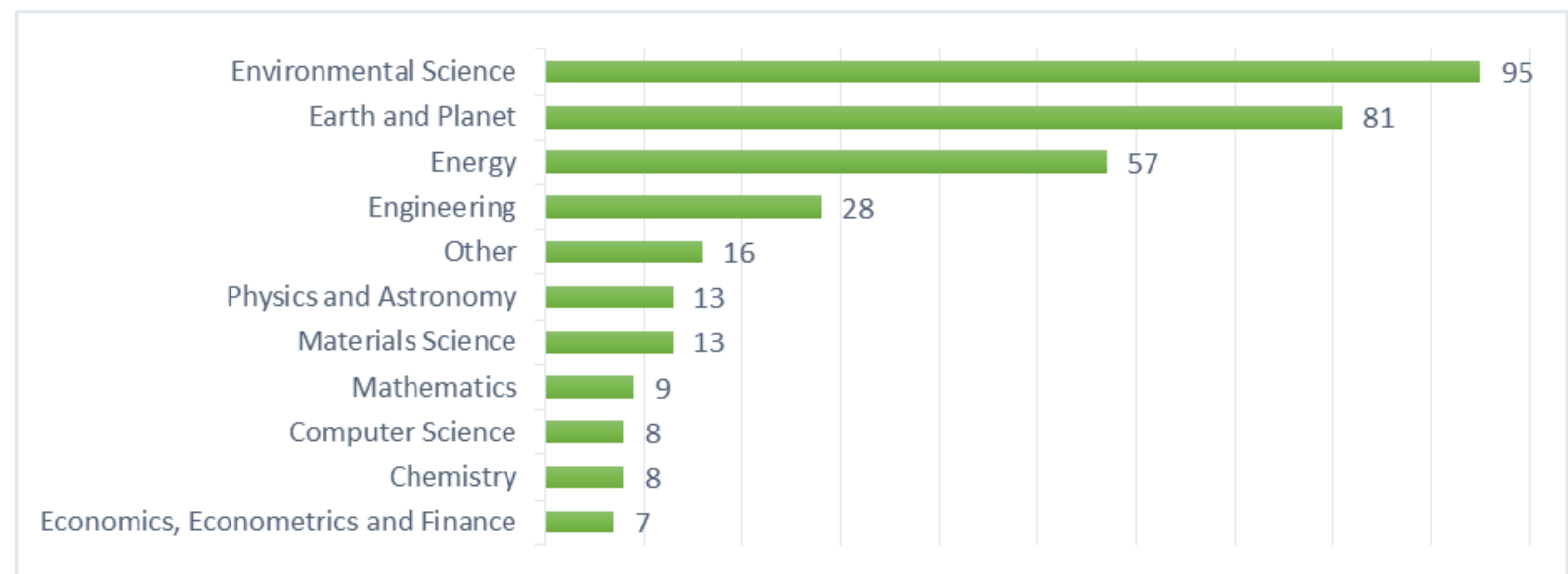

Source: Processed by Author

Figure 4.

Documents by country or territory

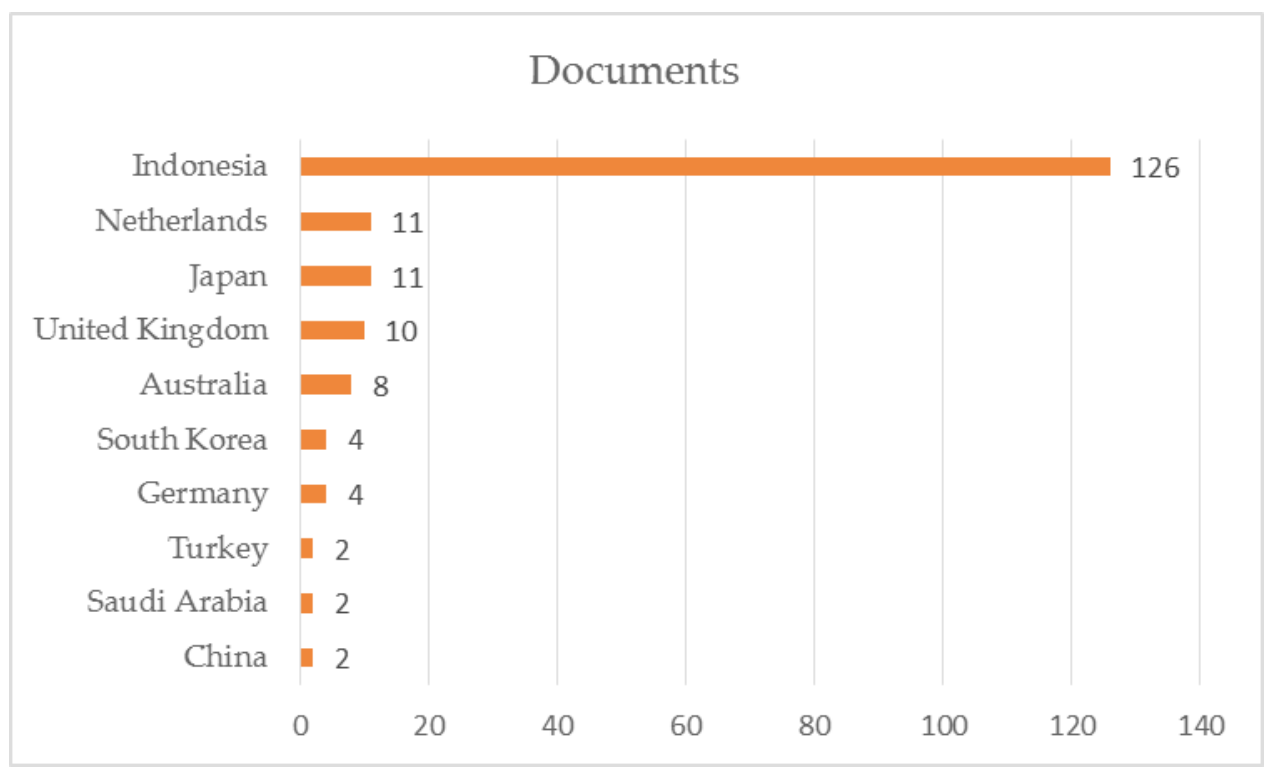

Source: Processed by Author

internal database, Scopus. Meanwhile, the bottom 16 sources of literature come from six subject areas, with details of Biochemistry, Genetics and Molecular Biology (1); Chemical Engineering (1); Business, Management and Accounting (2); Decision Sciences (3); Agricultural and Biological Sciences (4); Social Sciences (5).

Finally, looking at the distribution territory of the author's country of origin, Indonesia is the country of origin that produces the most articles on energy policy according to the research locus.
Even so, there are also a number of publications published by authors from other countries such as the Netherlands, Japan, United Kingdom, Australia, South Korea, Germany, Turkey, Saudi Arabia, and China.

\section{b) Bibliometric Mapping \\ 1) Most Cited and Productive Sources}

The first literature mapping looks at the sources or journals that are most cited when discussing energy policy issues. The following 
visualization illustrates the most cited sources of 177 citations (see: Figure 5), where when looking at citations, Energy Policy by Elsevier is the mostcited journal with five documents published. Energy Procedia and IOP Conference Series Earth and Environmental Science became the next most cited sources with 60 and 58 citations. Interestingly, although the IOP Conference Series Earth and Environmental Science have far less inequality in the number of citations with energy policy, the IOP Conference Series Earth and Environmental Science is the most common source that provides papers discussing energy policy in Indonesia (See: figure 6). The density network analyzed using the VOS Viewer also shows how these sources appear to be dominant compared to other sources with the publication of 58 conferences and proceedings. The second dominant sources are E3s Web of Conferences and Journal of Physics Conference Series with a total of 22 publications and 13 pieces of literature.

\section{2) Highest Occurrence of Keywords}

The next literature mapping that looks at the focus of the discussion raised on the topic of energy policy in Indonesia is seen from the keywords that appear in the analyzed articles. The main question in this study is to find out the development of the focus of the discussion raised on energy policy in Indonesia from year to year. Before that, we mapped out the clustering of the most discussed topics to those that were rarely discussed based on the keywords that appeared the most to those that rarely appeared. This

Figure 5.

\section{Most Cited Sources}

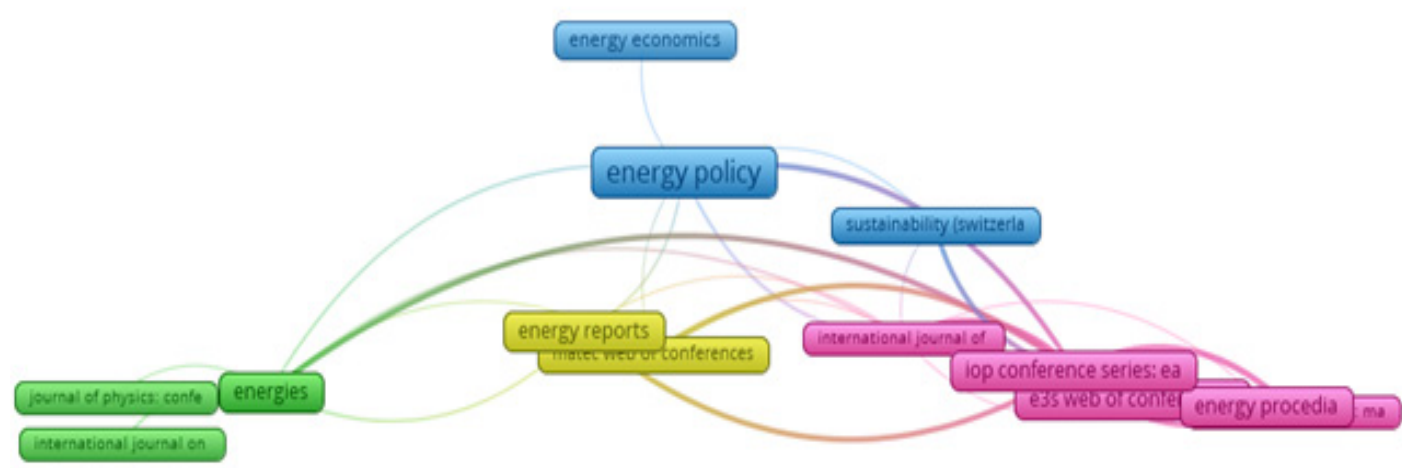

Source: Processed by Author

Figure 6.

Most productive sources

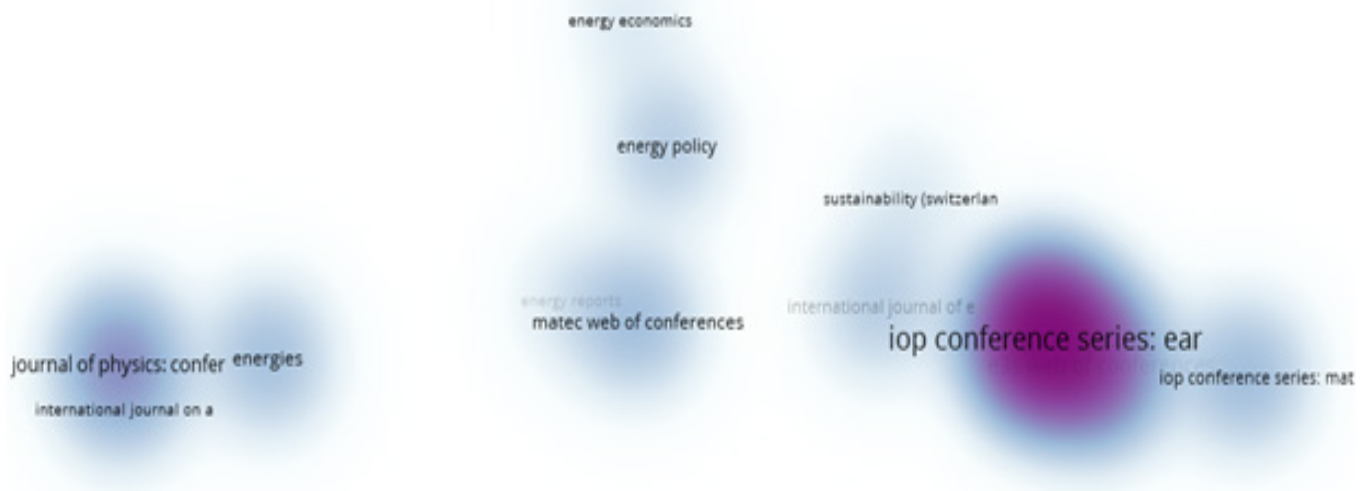

Source: Processed by Author 
Figure 7.

The Network Visualization of Most Frequently Occurring Keywords

in the Topic of Energy Policy in Indonesia

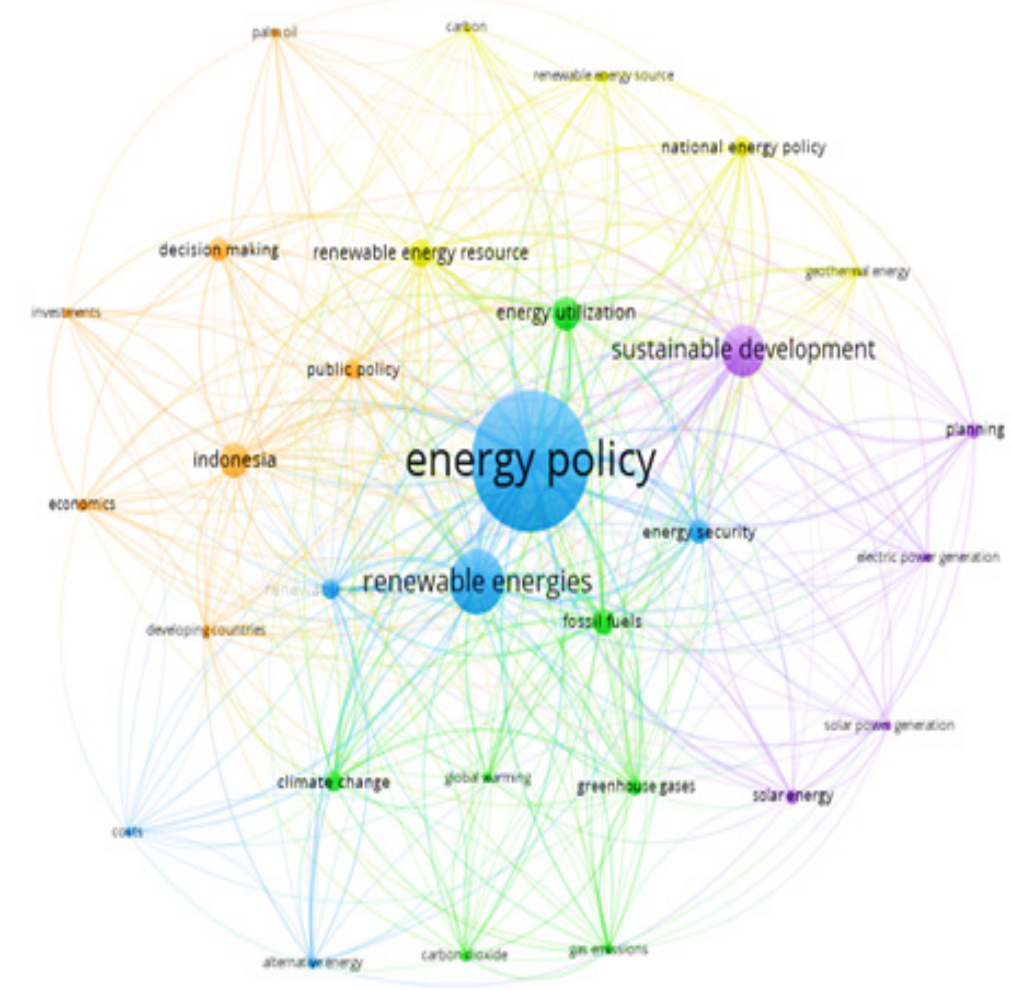

Source: Processed by Author

keyword and co-occurrence analysis used author keywords and index keywords in it, where the minimum occurrences were set to be the unit of analysis are two times and we take the top 30 keywords from the 1492 keywords that appear.

Figure 7 shows the strength of the network and words or keywords according to their visibility level in the Scopus database. Looking at the subject of energy policy in Indonesia, energy policy is the keyword that appears most often (116 times). Then, renewable energies and sustainable development are the keywords that appear the most (53 and 43 times) and are closely networked with energy policy.

\section{Results and Discussion}

\section{a) Mapping of Energy Policy Research Trends in Indonesia}

Keywords are a fairly representative subject in describing the focus of discussion raised by scholars in reviewing energy policy from time to time. We also present a visualization of keywords that appear from year to year (See: figure 8). We set a 5-year range as the visualization range, however, it still represents research conducted from 2003 to 2021 . The determination from 2016 to 2020 was taken because 2016 was the year the literature experienced an increase in publications and 2020 was the year in which the number of kinds of literature experienced a decline in publications. Meanwhile, 2017-2019 were the peak years where publications on energy policy in Indonesia had the most quantity.

The blue coloring shows the trend of discussion in the early years of energy policy in Indonesia. While increasingly leading to red coloring, it shows the trend of the discussion/issue raised in the latest publications. Figure 8 shows that before 2016 the keywords that appeared were 
economic related. Where this keyword arises from research that discusses how the city of Palembang in Indonesia can reduce energy consumption costs when using a low carbon system (Colenbrander et al., 2015). Then leading to 2016, the keywords that appear the most are developing countries. This keyword appears a lot because it is influenced by research (Ertugrul et al., 2016) which discussed the relationship between carbon dioxide (CO2) emissions, trade openness, actual income and energy consumption in the top ten carbon dioxide emitters in developing countries including Indonesia from 1971 to 2011. Next, around 2017, keywords were dominated by decision making and public policy, one of which was research by Prilandita et al. (2017) which uses solid waste management case studies to manufacture fertilizer and biogas to devise a system for assessing the performance of autonomous decision-making. In addition, the emergence of this keyword is also due to research through the development of agent-based models to review the simulation calculations of two biodiesel energy utilization policy options, while taking into account the adoption of the biodiesel industry in government bidding (Hidayatno et al., 2017). This year, policy is indeed a keyword that often appears because of the discussion regarding the evaluation of energy transition policies in the household cooking fuel conversion program from kerosene to LPG, which is considered a successful energy transition program that has been implemented since 2007 (Destyanto et al., 2017).

In 2018, some keywords that emerged began to lead to the discussion of alternative energy. Keywords such as Indonesia, energy utilization, planning, and carbon dioxide, solar energy, and solar power generation appear to be words that are widely discussed in this year's research. The keyword came up during a conversation about ESDM One Map Indonesia's support for the One Map Policy, which governs the management of geospatial data standardization and unification
(H. A. Setyowati et al., 2018). Then, a study that questions the application of a proper and reliable Photovoltaic System in Indonesia (H. M. Yudha et al., 2018), and the socialization of the use of solar energy through community service activities in areas where electricity is scarce (Cahyono et al., 2018). Topics include The Directorate General of Electricity commitment as the electricity sector regulation to encourage increased development of renewable power plants through a variety of policy plans (Sommeng \& Anditya, 2018), and a discussion of scenarios, as well as an examination of the causal relationship between energy consumption, carbon dioxide emissions, and economic growth in Indonesia between 2010 and 2025 (Nugrahanto et al., 2018). There are also keyword investments that arise as a result of the study of calculating the feasibility of investing in solar PV systems to provide quality energy supplies at the lowest possible cost (Murnandityo et al., 2018).

Next, in 2019, the main topics include various issues and are dominated by the keyword renewable energy. Although the topic of discussing renewable energy has been researched in previous years. However, this topic and matters related to renewable energy, including the urgency of reducing carbon or greenhouse gases, reviews of palm oil management, and other energy alternatives, have been widely studied since 2019 . For example, starting from a review of the need for increased responsibility and efficiency in the use of resources in the sustainable management of the palm oil industry (Kurniawan et al., 2019). Furthermore, in the context of renewable energy there is research that raises discussions about how to develop renewable energy from the policy context, how educational institutions can be involved in it, as well as the dynamics between actors in the formulation of renewable energy policies (Respitawulan \& Rahayu, 2019; Taqwa, 2019; S W Yudha \& Tjahjono, 2019).

Still related to renewable energy, the keywords energy security and energy policy 
appear in the discussion of calculating the comparison of energy production, balance, and ratio of clean energy, renewable index on biodiesel production as an alternative fuel (Siregar et al., 2019). Then the research discussing biofuels also found that the government can utilize financial engineering to advance the bioethanol program by utilizing excise and subsidy instruments (Purwoko, 2019) as a continuation of the change in the direction of energy management to renewable energy which is the result of massive energy consumption and mass production of carbon emissions, keywords such as global warming, gas emissions also appear. It is about weather that occurs due to global warming also affects the electricity sector (Handayani et al., 2019), and how the transportation sector also contributes greatly to gas emissions (Setiawan et al., 2019).

Shifting slightly towards 2020 , the discussion is still similar and varied. The keywords renewable energies and renewable energy resources reappeared in the discussion regarding the proposed alternative energy sources from tidal waves in bays and seas in the Bangka Belitung Islands (Pamungkas \& Jumnahdi, 2020; Rosa \& Prayitnoadi, 2020), and a review of the literature on geopolitics and renewable energy (Vakulchuk et al., 2020), until the side effects of improper processing of renewable energy and actually exacerbate environmental damage (Wang et al., 2020). Still related to renewable energy, the discussion about steps to make it happen brings up the keywords fossil fuels and sustainable development, where Vakulchuk et al. (2020) discusses about geopolitics in efforts to reduce fossil fuels. Then there is also a study on the development of microalgae for biodiesel in Indonesia by Punyanan (2020) and then Yandri et al. (2020) which attempt to conceptualize an Indonesian ICT-based energy security tracking system with specific indicators of renewable energy (RE) and energy efficiency (EE) as a result of the rise of smart cities, where the presence of these two elements invokes the term "sustainable development."

Furthermore, a discussion about climate change which is one of the "triggers" of the incessant efforts to switch to renewable energy also emerged. Authors Kristanto \& Rachmansyah (2020) analyze the potential utilization of waste generated from commercial areas such as rejectedderived fuel (RDF) in the cement industry to reduce CO2 emissions. Next, there is also a discussion about electricity problems in Indonesia. This study revolves around starting from research that will provide estimates of energy sources for power plants in Indonesia (Qolbi \& Utomo, 2020). Then, study how the energy trilemma contributes to Indonesia's private climate financing mobilization for renewable rural electrification (A. B. Setyowati, 2020) which gave rise to the words electric power generation, geothermal and alternative energy.

Shifting to 2021, the study of energy policy in Indonesia discusses the government's dominance over gas price determination which is also influenced by the economics of upstream projects, transmission rates, and natural gas infrastructure management, which raises keywords that often appears, namely costs (Iswandi et al., 2021). Then, national energy policy is also the dominant keyword that appears this year. This is influenced by research that encourages the use of nuclear energy potential as renewable energy following the National Energy Policy (KEN) (Permana et al., 2021). Interestingly, this year's article on the topic of national energy policy also discusses research in the pandemic era. Rosyidi et al. (2021) by reviewing community empowerment in the management of biogas as an electricity producer in one of Boyolali's villages to support the realization of renewable energy policies. Finally, returning to the keyword that is mentioned in various other versions but is cognate, namely renewable energy source, is mentioned again. These keywords reappear as a result of intriguing 
research from (Suhartini et al., 2021) regarding the potential use of cocoa as a renewable energy source, where cocoa is also one of the most widely produced plantation commodities in Indonesia.

Authors, S W Yudha et al. (2021) who previously researched the mapping of stakeholders in the NRE industry in Indonesia in 2019 (Satya Widya Yudha \& Tjahjono, 2019) then review it more deeply by conducting FGDs with stakeholders from the ministry of energy to the community and providing knowledge about the views and challenges that are important for the energy transition in the country, in addition to perceptions of developing renewable energy sources. Next, there is also a study that analyzes renewable energy sources (wind, hydro, and geothermal) and carbon emissions from four ASEAN countries (Indonesia, Thailand, Vietnam, and the Philippines) between 2000 and 2019 by Wu et al. (2021), where they discovered that green energy has a significant impact by making a beneficial and critical contribution to limiting the rise of carbon emissions in the economy or industrialization in various ASEAN countries.

Literature mapping with clustering was also carried out to determine the category of groups in energy policy research in Indonesia. In keyword clustering, it appears that 5 different colors indicate 5 clusters of the top keywords. This cluster illustrates the major topics raised by academics in reviewing energy policy in Indonesia. Following what colleagues (Khanra et al., 2021) did in manually grouping the findings, we grouped them into 5 topic groups by looking at the density of keywords (see: Figure 9) which are detailed in the table 2 .

In the economic cluster, energy policy in Indonesia examines the use of biodiesel, which is one of the largest commodities in Indonesia, analysis of energy consumption in Indonesia from various perspectives, to the study of potential investments in various alternative energies. Then, this electricity cluster discusses studies about research and studies on various alternative

Figure 8.

The Network Visualization of Keywords in the Topic of Energy Policy in Indonesia Based on Years

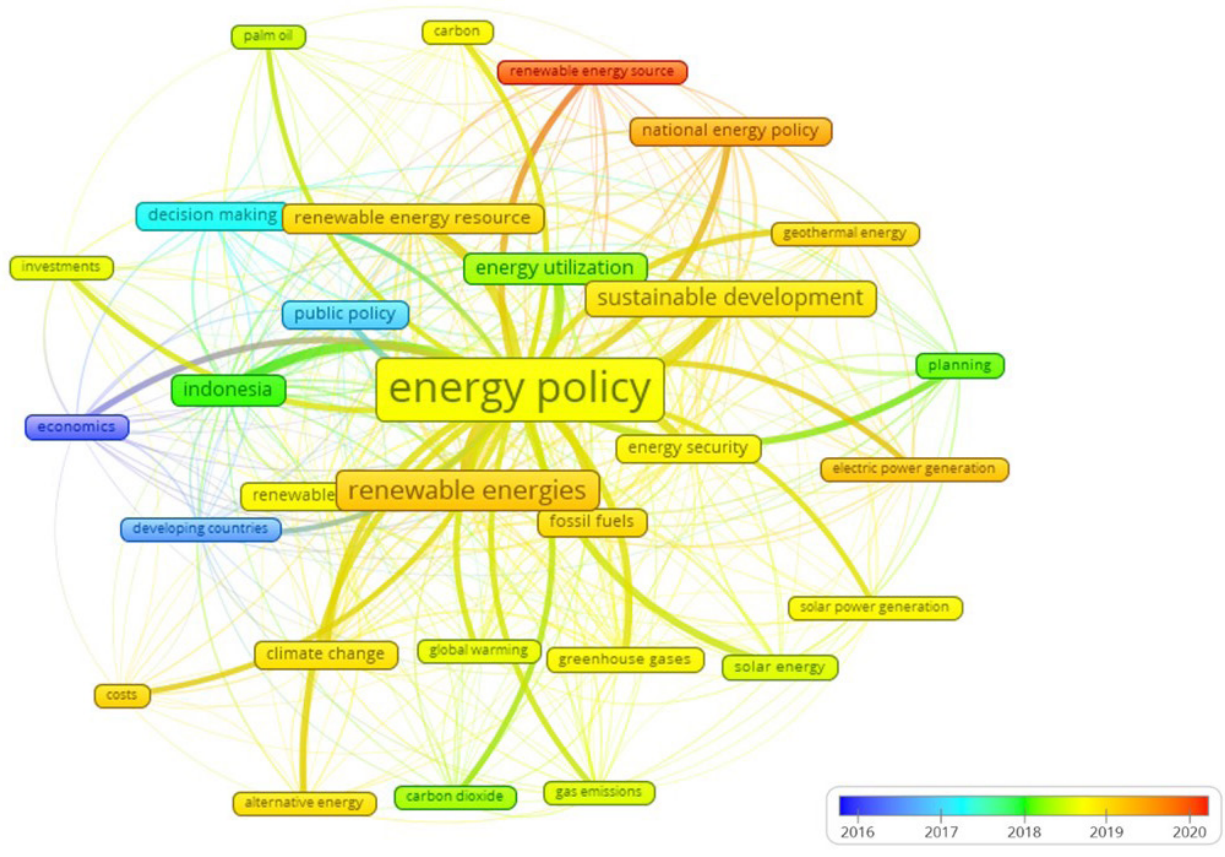

Source: Processed by Author 
Figure 9.

The Network Visualization of Most Frequently Occurring Keywords

In The Topic Of Energy Policy In Indonesia by Cluster

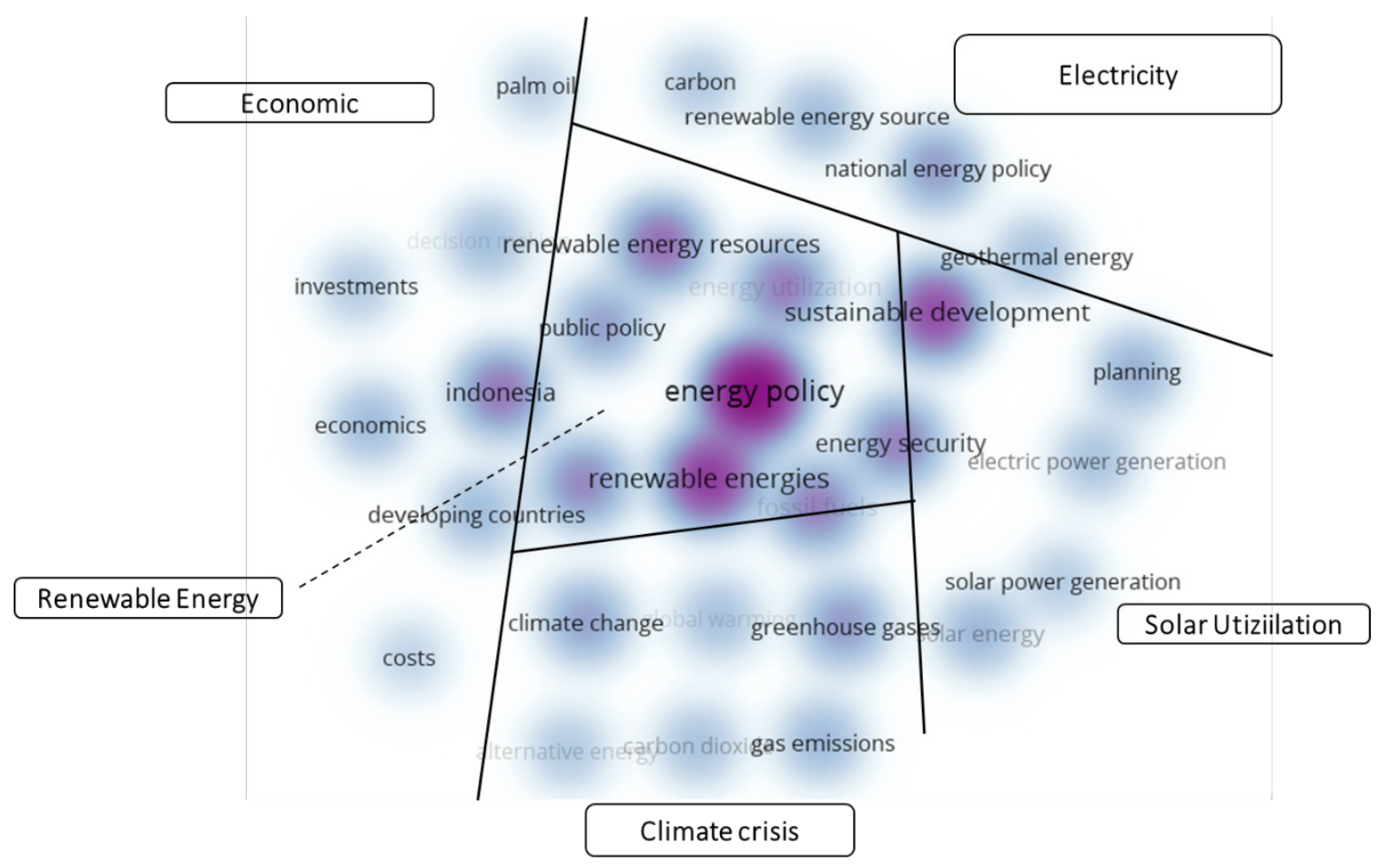

Source: Processed by Author.

Table 2. Keyword Clustering

\begin{tabular}{|c|c|}
\hline Cluster & Keywords \\
\hline Economic & $\begin{array}{l}\text { palm oil, investments, Indonesia, } \\
\text { economics, developing countries, costs, } \\
\text { decision making; }\end{array}$ \\
\hline Electricity & $\begin{array}{l}\text { carbon, geothermal energy, national } \\
\text { energy policy, renewable energy } \\
\text { resources, renewable energy sources; }\end{array}$ \\
\hline Solar utilization & $\begin{array}{l}\text { electric power generation, planning, } \\
\text { solar energy, solar power generation, } \\
\text { sustainable development. }\end{array}$ \\
\hline Climate crisis & $\begin{array}{l}\text { carbon dioxide, climate change, energy } \\
\text { utilization, fossil fuels, gas emissions, } \\
\text { global warming, greenhouse gases; }\end{array}$ \\
\hline $\begin{array}{l}\text { Renewable } \\
\text { energy }\end{array}$ & $\begin{array}{l}\text { alternative energy, energy policy, energy } \\
\text { security, renewable energies, renewable } \\
\text { energy }\end{array}$ \\
\hline
\end{tabular}

Source: Processed by Author

energies to generate electricity for consumption as well as industry and transportation. One of them is geothermal power plants which can be found in several areas in Indonesia such as in Java and Sumatra (Ibrohim et al., 2019; Muhrom et al., 2017). Furthermore, still discussing the various alternatives to produce electrical energy, the solar utilization cluster specifically discusses the various potentials for developing solar power in Indonesia which are encouraged by various parties from the government to the community.

Next, the climate crisis cluster examines carbon trading carried out by Indonesia as well as various studies that encourage efforts to reduce emissions that can have an impact on climate change. Finally, the renewable energy cluster is very close to the main topic of energy policy. In this cluster, the study discusses more about the use of natural resources owned by Indonesia that can be used as alternative energy if managed optimally, to studies on how policy-making actors are involved in managing energy policies in Indonesia.

\section{b) Discussion}

This study highlights the development of publications on energy policy topics in Indonesia from 2003 to 2021 published in Scopus. This research provides a comprehensive 
overview of studies that highlight Indonesia's energy policy and trending issues of interest. Interestingly, the previous mapping findings found that renewable energy dominates energy policy issues in Indonesia. The findings also show that the direction of the topic of energy policy in Indonesia towards renewable energy has touched the level of policy input, process, and output. Where research on the importance of switching to renewable energy for continued sustainability, recommendations for potential domestic natural resources that can be a source of renewable energy to mapping stakeholders in the context of renewable energy are topics that look at potential policy inputs. Researchers also look at the renewable energy policy process in terms of calculating the use of renewable energy compared to conventional energy or analyzing the comparison of biodiesel use with the private sector and the government. Meanwhile, in terms of policy output, researchers have also reviewed the One Map Policy and developed what is contained in the national energy policy (KEN).
However, the topic of renewable energy dominates in energy policy research in Indonesia. There are also interesting studies that also highlight energy policy on the other side, such as research on evaluating energy transition policies in the kerosene to LPG conversion program for household cooking fuel consumption (Destyanto et al., 2017). In addition, data collection carried out by pulling the latest and most recent data also captures research on the topic of energy policy in Indonesia during the pandemic. There is a review of support for realizing renewable energy policies through community empowerment in one area in Indonesia.

In order to complement the map of energy policy literature in Indonesia, the researcher suggests several future research questions based on the results of the clustering of bibliometric analysis findings described previously as follows.

\section{Conclusion and Limitations}

The mapping of energy policy research trends in Indonesia that has been described

Table 3.

Future Research Questions

\begin{tabular}{|c|c|c|c|}
\hline Number & Cluster & Future Research Questions & Authors \\
\hline \multirow[t]{2}{*}{1} & Economic & $\begin{array}{l}\text { Looking at the negative impacts from an economic, ecological and social } \\
\text { perspective, what are the steps to save the ecology that can be taken by } \\
\text { various stakeholders? And how is the comparative analysis between the } \\
\text { benefits obtained if continuing production and the losses due to ecological } \\
\text { damage and social conflict? }\end{array}$ & $\begin{array}{l}\text { (Dharmawan et al., } \\
\text { 2020) }\end{array}$ \\
\hline & & $\begin{array}{l}\text { How strong is political influence in pushing towards better use of energy } \\
\text { policies? How does the financial impact compare between conventional } \\
\text { and renewable energy management? }\end{array}$ & $\begin{array}{l}\text { (Respitawulan \& } \\
\text { Rahayu, 2019) }\end{array}$ \\
\hline 2 & Electricity & $\begin{array}{l}\text { Based on how energy management in the electricity production process } \\
\text { by the government has not been able to move to renewable energy, is the } \\
\text { role of the private sector really needed? }\end{array}$ & $\begin{array}{l}\text { (S W Yudha et al., } \\
\text { 2021) }\end{array}$ \\
\hline 3 & Solar utilization & $\begin{array}{l}\text { Are there any negative impacts from the use of solar PV that need to be } \\
\text { anticipated, especially in terms of policies to protect the environment? }\end{array}$ & $\begin{array}{l}\text { (H. M. Yudha et al., } \\
\text { 2018) }\end{array}$ \\
\hline 4 & Climate Crisis & $\begin{array}{l}\text { How can the impact of trade openness on carbon dioxide emissions in } \\
\text { Indonesia be analyzed not only quantitatively but also qualitatively, and } \\
\text { how is this regulation managed in energy policy in Indonesia? }\end{array}$ & (Ertugrul et al., 2016) \\
\hline \multirow[t]{3}{*}{5} & $\begin{array}{l}\text { Renewable } \\
\text { energy }\end{array}$ & $\begin{array}{l}\text { How does the implementation of the law compare to the public and } \\
\text { industry and what is the impact between them? }\end{array}$ & $\begin{array}{l}\text { (Darwanto et al., } \\
\text { 2020) }\end{array}$ \\
\hline & & $\begin{array}{l}\text { How and to what extent are emerging fiscal plans facilitating the } \\
\text { transition to low-carbon energy and achieving the country's energy goals, } \\
\text { including energy access, security and the environment? }\end{array}$ & $\begin{array}{l}\text { (A. B. Setyowati, } \\
\text { 2021) }\end{array}$ \\
\hline & & $\begin{array}{l}\text { What are the environmental and social externalities of oil palm, which } \\
\text { was previously considered a renewable energy, namely biofuel? }\end{array}$ & (Prananta, 2021) \\
\hline
\end{tabular}

Source: Processed by Author 
previously shows how energy policy research in Indonesia is quite broad and diverse. The direction of writing that outlines how researchers are trying to encourage the realization of policies on the use of renewable energy has also been seen, along with various studies that explain the adverse effects of using fossil fuels. Overall, the research findings use very diverse perspectives and show positive directions to encourage environmental sustainability. Thus, this study also has some limitations. First, homogeneity appears in the findings, which are dominated by large "renewable energy" objects. This is also influenced by the analyzed sources that only use one database. Second, although in general, it has described popular issues from keywords, the authors have not discussed the most influential articles and authors in energy policy research in Indonesia.

On the other hand, the empirical context, the development of energy policy in Indonesia has not been covered. This is important to describe the alignment of educational developments and the reality of existing policies. For further studies, researchers can consider expanding the scope of literature sources, developing components from bibliometric studies as well as comparing literature and factual studies of energy policy in Indonesia. Future researchers who are interested in reviewing other energy policies can also fill in the gaps that are missing or have not been widely discussed from the various popular issues mentioned earlier.

\section{References}

Adedayo, H. B., Adio, S. A., \& Oboirien, B. O. (2021). Energy research in Nigeria: A bibliometric analysis. Energy Strategy Reviews, 34(February), 100629. https://doi. org/10.1016/j.esr.2021.100629

Aized, T., Shahid, M., Bhatti, A. A., Saleem, M., \& Anandarajah, G. (2018). Energy security and renewable energy policy analysis of Pakistan. Renewable and Sustainable Energy Reviews, 84, 155-169. https://doi. org/10.1016/j.rser.2017.05.254

Akbar, G. G. (2020). Corruption In Indonesia, A Bibliometric Analysis. International Journal of Psychosocial Rehabilitation, 24(4), 5325-5335. https://doi.org/10.37200/ ijpr/v24i4/pr201630

Annibaldi, V., Condemi, A., Cucchiella, F., Gastaldi, M., \& Rotilio, M. (2020). Renewable Energy Policies: Bibliometric Review and Policy Implications. Environmental and Climate Technologies, 24(3), 403-417. https://doi. org/10.2478/rtuect-2020-0112

Apergis, N., \& Gangopadhyay, P. (2020). The asymmetric relationships between pollution, energy use and oil prices in Vietnam: Some behavioural implications for energy policymaking. Energy Policy, 140. https://doi. org/10.1016/j.enpol.2020.111430

Apriliyanti, I. D., \& Alon, I. (2017). Bibliometric analysis of absorptive capacity. International Business Review, 26(5), 896-907. https:// doi.org/10.1016/j.ibusrev.2017.02.007

Ardo, S., Fernandez Rivas, D., Modestino, M. A., Schulze Greiving, V., Abdi, F. F., Alarcon Llado, E., Artero, V., Ayers, K., Battaglia, C., Becker, J.-P., Bederak, D., Berger, A., Buda, F., Chinello, E., Dam, B., Di Palma, V., Edvinsson, T., Fujii, K., Gardeniers, H., ... Westerik, P. (2018). Pathways to electrochemical solar-hydrogen technologies. Energy and Environmental Science, 11(10), 2768-2783. https://doi.org/10.1039/c7ee03639f

Aydoğan, B., \& Vardar, G. (2020). Evaluating the role of renewable energy, economic growth and agriculture on $\mathrm{CO} 2$ emission in $\mathrm{E} 7$ countries. International Journal of Sustainable Energy, 39(4), 335-348. https://doi.org/10.1080/ 14786451.2019.1686380

Banja, M., Sikkema, R., Jégard, M., Motola, V., \& Dallemand, J.-F. (2019). Biomass for energy in the EU - The support framework. 
Energy Policy, 131, 215-228. https://doi. org/10.1016/j.enpol.2019.04.038

Best, R., \& Burke, P. J. (2018). Adoption of solar and wind energy: The roles of carbon pricing and aggregate policy support. Energy Policy, 118, 404-417. https://doi.org/10.1016/j. enpol.2018.03.050

Boyack, K. W., \& Klavans, R. (2010). Co-citation analysis, bibliographic coupling, and direct citation: Which citation approach represents the research front most accurately? Journal of the American Society for Information Science and Technology, 61(12), 2389-2404.

Bretas, V. P. G., \& Alon, I. (2021). Franchising research on emerging markets : Bibliometric and content analyses. Journal of Business Research, 133(April 2020), 51-65. https:// doi.org/10.1016/j.jbusres.2021.04.067

Brika, S. K. M., Algamdi, A., Chergui, K., \& Musa, A. A. (2021). Quality of Higher Education: A Bibliometric Review Study. 6(May), 1-15. https://doi.org/10.3389/ feduc.2021.666087

Bulavskaya, T., \& Reynès, F. (2018). Job creation and economic impact of renewable energy in the Netherlands. Renewable Energy, 119, 528-538. https://doi.org/10.1016/j. renene.2017.09.039

Bullock, R., \& Lawler, J. (2015). Community forestry research in Canada: A bibliometric perspective. Forest Policy and Economics, 59(November), 47-55. https://doi. org/10.1016/j.forpol.2015.05.009

Cabinet Secretariat of The Republic of Indonesia. (2021). COP26: President Jokowi Says Indonesia is Committed to Tackling Climate Change. Office of Assistant to Deputy Cabinet Secretary. https://setkab.go.id/en/cop26president-jokowi-says-indonesia-iscommitted-to-tackling-climate-change/

Cahyono, Y., Setyaningrum, Y., Sarasechan, A., Nafsi, R. G., Setiyono, Salamah, M. D., Triyuliana, N. A., Silvia, L., Subagyo, B.
A., Zainuri, M., Triwikantoro, Baqiya, M. A., Endarko, Asrori, M. Z., Pratapa, S., Suasmoro, \& Darminto. (2018). Socialization of Solar Energy Utilization in Ponpes Al Hidayah, Arjasa, Kangean Island, Sumenep (D. U.A., K. A., L. N.A., \& S. N. (eds.); Vol. 997, Issue 1). Institute of Physics Publishing. https://doi. org/10.1088/1742-6596/997/1/012047

Cao, Q., Vuong, Q., Pham, H., Luong, D., \& Ho, M. (2021). A Bibliometric Review of Research on International Students 'Mental Health : Science Mapping of the Literature from 1957 to 2020.781-794.

Chen, C., Li, D., \& Man, C. (2018). Toward sustainable development? A bibliometric analysis of PPPrelated policies in China between 1980 and 2017. Sustainability (Switzerland), 11(1). https://doi.org/10.3390/su11010142

Cheng, M., \& Edwards, D. (2016). A Tri-Method Approach To A Review of Adventure Tourism Literature: Bibliometric Analysis, Content Analysis, and A Quantitative Systematic Literature Review. XX(X), 1-24. https://doi. org/10.1177/1096348016640588

Chiou-Wei, S. Z., Chen, C.-F., \& Zhu, Z. (2008). Economic growth and energy consumption revisited - Evidence from linear and nonlinear Granger causality. Energy Economics, 30(6), 3063-3076. https://doi. org/10.1016/j.eneco.2008.02.002

Colenbrander, S., Gouldson, A., Sudmant, A. H., \& Papargyropoulou, E. (2015). The economic case for low-carbon development in rapidly growing developing world cities: A case study of Palembang, Indonesia. Energy Policy, 80, 24-35. https://doi. org/10.1016/j.enpol.2015.01.020

Darwanto, Santosa, P. B., Handayani, H. R., Aminata, J., Arianti, F., \& Gozhali, I. (2020). Does formal constraints reduce $\mathrm{CO} 2$ emissions? Indonesia's empirical case. International Journal of Energy Economics and Policy, 
10(1), 236-241.https://doi.org/10.32479/ ijeep. 8510

Destyanto, A. R., Silalahi, T. D., \& Hidayatno, A. (2017). Exploration of government policy structure which support and block energy transition process in Indonesia using system dynamics model (W. H. (ed.); Vol. 94, Issue 1). Institute of Physics Publishing. https://doi. org/10.1088/1755-1315/94/1/012155

Dharmawan, A. H., Fauzi, A., Putri, E. I. K., Pacheco, P., Dermawan, A., Nuva, N., Amalia, R., \& Sudaryanti, D. A. (2020). Bioenergy policy: The biodiesel sustainability dilemma in Indonesia. International Journal of Sustainable Development and Planning, 15(4), 537-546. https://doi.org/10.18280/ijsdp.150414

Dinu, M., \& Constantin, M. (2020). Bibliometric Analysis of the Field of Green Public Procurement. January 2021. https://doi. org/10.24818/EA/2020/53/71

Droulia, F., \& Charalampopoulos, I. (2021). Future Climate Change Impacts on European Viticulture: A Review on Recent Scientific Advances. Atmosphere, 12(4), 495.

Ebrahimigharehbaghi, S., Qian, Q. K., Meijer, F. M., \& Visscher, H. J. (2019). Unravelling Dutch homeowners' behaviour towards energy efficiency renovations: What drives and hinders their decision-making? Energy Policy, 129, 546-561. https://doi. org/10.1016/j.enpol.2019.02.046

Ertugrul, H. M., Cetin, M., Seker, F., \& Dogan, E. (2016). The impact of trade openness on global carbon dioxide emissions: Evidence from the top ten emitters among developing countries. Ecological Indicators, 67, 543-555. https://doi.org/10.1016/j. ecolind.2016.03.027

Febriadi, B., Zamzami, Z., Yunefri, Y., \& Wanto, A. (2018). Bipolar function in backpropagation algorithm in predicting Indonesia's coal exports by major destination countries. IOP Conference Series: Materials Science and Engineering, 420(1). https://doi. org/10.1088/1757-899X/420/1/012087 Gümüş, S., Bellibaş, M. Ş., Gümüş, E., \& Hallinger, P. (2020). Science mapping research on educational leadership and management in Turkey: a bibliometric review of international publications. School Leadership \& Management, 40(1), 23-44.

Hache, E., \& Palle, A. (2019). Renewable energy source integration into power networks, research trends and policy implications: A bibliometric and research actors survey analysis. Energy Policy, 124, 23-35. https:// doi.org/10.1016/j.enpol.2018.09.036

Handayani, K., Filatova, T., \& Krozer, Y. (2019). The vulnerability of the power sector to climate variability and change: Evidence from Indonesia. Energies, 12(19). https:// doi.org/10.3390/en12193640

Hartono, D., \& Resosudarmo, B. P. (2008). The economy-wide impact of controlling energy consumption in Indonesia: An analysis using a Social Accounting Matrix framework. Energy Policy, 36(4), 1404-1419. https:// doi.org/10.1016/j.enpol.2007.12.011

Heryana, G., Prasetya, S., Adhitya, M., \& Sumarsono, D. A. (2018). Power consumption analysis on large-sized electric bus (P. C.R., J. F.H., K. E., \& S. E.A. (eds.); Vol. 105, Issue 1). Institute of Physics Publishing. https://doi. org/10.1088/1755-1315/105/1/012041

Hidayatno, A., Vicky, L. R., \& Destyanto, A. R. (2017). Exploration of agent of change's role in biodiesel energy transition process using agent-based model (W. H. (ed.); Vol. 94, Issue 1). Institute of Physics Publishing. https://doi.org/10.1088/17551315/94/1/012156

Ibrohim, A., Prasetyo, R. M., \& Rekinagara, I. H. (2019). Understanding Social Acceptance of Geothermal Energy: A Case Study from Mt. Lawu, Indonesia. 254(1). https://doi. org/10.1088/1755-1315/254/1/012009 
Indonesia, C. (2019). Musim Kemarau Indonesia, NTT Jadi Daerah Terkering pada 2019. 28/12/2019.

International Energy Agency (IEA). (2020). Report extract Trade Coal 2020. https://www.iea. org/reports/coal-2020/trade

Iswandi, E., Supriyadi, I., \& Thamrin, S. (2021). Understanding gas prices: An overview of regulations and components affecting the Indonesian natural gas prices. 753(1). https://doi.org/10.1088/1755$1315 / 753 / 1 / 012026$

Jung, M. (2006). Host country attractiveness for CDM non-sink projects. Energy Policy, 34(15), 2173-2184. https://doi. org/10.1016/j.enpol.2005.03.014

Karatayev, M., \& Hall, S. (2020). Establishing and comparing energy security trends in resource-rich exporting nations (Russia and the Caspian Sea region). Resources Policy, 68. https://doi.org/10.1016/j. resourpol.2020.101746

Khan, M. H., Muktar, S. N., Khan, M. H., \& Muktar, S. N. (2020). Cogent Business \& Management A bibliometric analysis of green human resource management based on scopus platform MANAGEMENT | REVIEW ARTICLE A bibliometric analysis of green human resource management based on scopus platform. Cogent Business \& Management, 7(1). https://doi.org/10.1080/23311975. 2020.1831165

Khanra, S., Dhir, A., \& Kaur, P. (2021). Bibliometric analysis and literature review of ecotourism : Toward sustainable development.37(October 2020 ). https://doi.org/10.1016/j. tmp.2020.100777

Kristanto, G. A., \& Rachmansyah, E. (2020). The application of Refuse Derived Fuel (FDR) from commercial solid wastes to reduce CO2 emissions in the cement industry: A preliminary study. 423(1). https://doi. org/10.1088/1755-1315/423/1/012014
Kumar, S. (2016). Assessment of renewables for energy security and carbon mitigation in Southeast Asia: The case of Indonesia and Thailand. Applied Energy, 163, 63-70. https://doi.org/10.1016/j. apenergy.2015.11.019

Kurniawan, M. P., Guritno, A. D., Purwantana, B., \& Supartono, W. (2019). Determining transparency on material and energy flow in Palm Oil industry. 355(1). https://doi. org/10.1088/1755-1315/355/1/012015

Lee, C. Y., Kaneko, S., \& Sharifi, A. (2020). Effects of building types and materials on household electricity consumption in Indonesia. Sustainable Cities and Society, 54. https:// doi.org/10.1016/j.scs.2019.101999

Li, F. G. N., \& Pye, S. (2018). Uncertainty, politics, and technology: Expert perceptions on energy transitions in the United Kingdom. Energy Research and Social Science, 37, 122-132. https://doi.org/10.1016/j. erss.2017.10.003

Lotka, A. J. (1926). The frequency distribution of scientific productivity. Journal of the Washington Academy of Sciences, 16(12), 317-323.

Malhi, G. S., Kaur, M., \& Kaushik, P. (2021). Impact of climate change on agriculture and its mitigation strategies: A review. Sustainability, 13(3), 1318.

Marquardt, J. (2014). A Struggle of Multi-level Governance: Promoting Renewable Energy in Indonesia. Energy Procedia, 58, 87-94. https://doi.org/10.1016/j. egypro.2014.10.413

Masih, A. M. M., \& Masih, R. (1996). Energy consumption, real income and temporal causality: Results from a multi-country study based on cointegration and errorcorrection modelling techniques. Energy Economics, 18(3), 165-183. https://doi. org/10.1016/0140-9883(96)00009-6 
Mihajlovic, L. S., \& Trajkovic, S. (2018). The importance of energy for the economy, sustainable development and environmental protection: An economic aspect. Journal of Process Management. New Technologies, 6(1), 20-26. https://doi. org/10.5937/jouproman6-16221

Mufson, S., Mooney, C., Eilperin, J., \& Muyskens, J. (2019). $20 \mathrm{C}$ beyond the limit: Extreme climate change has arrived in America. Washington Post, August, 13.

Muhrom, M. F., Nitibaskara, T. R. R., Herdiansyah, H., \& Sari, R. (2017). The Scenario of the Potential Analysis Alternative Energy in Order to Strengthening District's Energy Resilience (The Case Study in South Sumatera Province) (G. F.L. (ed.); Vol. 88, Issue 1). Institute of Physics Publishing. https://doi.org/10.1088/17551315/88/1/012028

Muhtar, E. A., Rusli, B., Karlina, N., \& Candradewini, C. (2021). Bibliometric Analysis and Visualization of Energy Economics and Policy in Scopus from 2010 to 2021. 11(6), 503-507.

Mujiyanto, S., \& Tiess, G. (2013). Secure energy supply in 2025: Indonesia's need for an energy policy strategy. Energy Policy, 61, 31-41. https://doi.org/10.1016/j. enpol.2013.05.119

Mulet-Forteza, C., Genovart-Balaguer, J., Merigó, J. M., \& Mauleon-Mendez, E. (2019). Bibliometric structure of IJCHM in its 30 years. International Journal of Contemporary Hospitality Management.

Murnandityo, A., Setiawan, E. A., \& Fajardhani. (2018). Study and model development of renewable energy investment feasibility under willingness and ability to pay approach (P. C.R., J. F.H., K. E., \& S. E.A. (eds.); Vol. 105, Issue 1). Institute of Physics Publishing. https://doi.org/10.1088/17551315/105/1/012032
Nicula, V., Spânu, S., \& Neagu, R. E. (2013). Regional Tourism Development in Romania - Consistency with Policies and Strategies Developed at EU Level. Procedia Economics and Finance, 6, 530-541. https://doi. org/https://doi.org/10.1016/S22125671(13)00171-8

Nugrahanto, C. A., Windarta, J., \& Aminata, J. (2018). Analysis of Causality Relationship Energy Consumption and CO 2 Emissions to Economic Growth based on the LEAP Model Case Study of Energy Consumption in Indonesia 2010-2025) (W. B., Hadiyanto, \& Maryono (eds.); Vol. 73). EDP Sciences. https://doi. org/10.1051/e3sconf/20187301002

Nyga-Lukaszewska, H., Aruga, K., \& StalaSzlugaj, K. (2020). Energy security of Poland and coal supply: Price analysis. Sustainability (Switzerland), 12(6). https:// doi.org/10.3390/su12062541

Özcan, S. (2013). Securitization of energy through the lenses of Copenhagen School. Orlando.

Pamungkas, A., \& Jumnahdi, M. (2020). The Study of Tidal Currents as Renewable Energy in Kelabat Bay, Bangka Belitung. IOP Conference Series: Earth and Environmental Science, 599(1). https://doi.org/10.1088/17551315/599/1/012001

Pasqui, M., \& Di Giuseppe, E. (2019). Climate change, future warming, and adaptation in Europe. Animal Frontiers, 9(1), 6-11.

Pegels, A., Vidican-Auktor, G., Lütkenhorst, W., \& Altenburg, T. (2018). Politics of Green Energy Policy. Journal of Environment and Development, 27(1), 26-45. https://doi. org/10.1177/1070496517747660

Pereira, G. I., Specht, J. M., Silva, P. P., \& Madlener, R. (2018). Technology, business model, and market design adaptation toward smart electricity distribution: Insights for policy making. Energy Policy, 121, 426-440. https://doi.org/10.1016/j. enpol.2018.06.018 
Permana, S., Trianti, N., \& Rahmansyah, A. (2021). Nuclear energy contribution potential to secure electricity demand with low carbon emission and low risk of power plant in Indonesia. 753(1). https://doi. org/10.1088/1755-1315/753/1/012048

Polzin, F., Egli, F., Steffen, B., \& Schmidt, T. S. (2019). How do policies mobilize private finance for renewable energy?-A systematic review with an investor perspective. Applied Energy, 236, 1249-1268. https://doi. org/10.1016/j.apenergy.2018.11.098

Prananta, W. (2021). Assessment of Indonesia 's Future Renewable Energy Plan: A Meta-Analysis of Biofuel Energy Return on Investment ( EROI).

Prilandita, N., McLellan, B., \& Tezuka, T. (2017). Evaluation method for autonomous decision-making performance in energy and environmental innovations: A case study of an Indonesian community. Sustainability (Switzerland), 9(1). https:// doi.org/10.3390/su9010080

Prontera, A. (2009). Energy policy: Concepts, actors, instruments and recent developments. World Political Science, 5(1).

Punyanan, J. P. (2020). Biorefinery Approach for Biodiesel Production from Microalgae. 520(1). https://doi.org/10.1088/17551315/520/1/012008

Purkus, A., Gawel, E., Szarka, N., Lauer, M., Lenz, V., Ortwein, A., Tafarte, P., Eichhorn, M., \& Thrän, D. (2018). Contributions of flexible power generation from biomass to a secure and cost-effective electricity supply-a review of potentials, incentives and obstacles in Germany. Energy, Sustainability and Society, 8(1). https://doi.org/10.1186/s13705018-0157-0

Purwoko. (2019). Financial engineering to promote renewable energy in Indonesia: Case study bioethanol. IOP Conference Series: Earth and Environmental Science, 345(1),
0-7. https://doi.org/10.1088/17551315/345/1/012006

Putrasari, Y., Praptijanto, A., Santoso, W. B., \& Lim, O. (2016). Resources, policy, and research activities of biofuel in Indonesia: A review. Energy Reports, 2, 237-245. https://doi. org/10.1016/j.egyr.2016.08.005

Qolbi,A., \&Utomo, A. (2020). Forecasting Indonesia's electricity generation: An application of long-range energy alternatives planning. 551(1). https://doi.org/10.1088/17551315/551/1/012007

Rabe, M., Streimikiene, D., \& Bilan, Y. (2019). The concept of risk and possibilities of application of mathematical methods in supporting decision making for sustainable energy development. Sustainability (Switzerland), 11(4). https://doi. org/10.3390/su11041018

Ramadhan, A. (2020). BMKG Sebut Curah Hujan di Jakarta Awal 2020 Paling Ekstrem dalam Sejarah. 03/01/2020.

Ramaswami, A., Zimmerman, J. B., \& Mihelcic, J. R. (2007). Integrating developed and developing world knowledge into global discussions and strategies for sustainability. 2. Economics and governance. Environmental Science and Technology, 41(10), 3422-3430. https://doi.org/10.1021/es0603047

Reddy, D., Haque, Z., Schramm, H., \& Kummer, S. (2018). Resources, Conservation \& Recycling A review of green supply chain management: From bibliometric analysis to a conceptual framework and future research directions. Resources, Conservation \& Recycling, 139(July), 150-162. https://doi.org/10.1016/j. resconrec.2018.08.004

Respitawulan, A., \& Rahayu, A. Y. S. (2019). The Role of Renewable Energy to Reduce Climate Change: Perspective of Policy Content and Context. 328(1). https://doi. org/10.1088/1755-1315/328/1/012005 
Rialti, R., Marzi, G., Ciappei, C., \& Busso, D. (2019). Big data and dynamic capabilities : a bibliometric analysis and systematic literature review capabilities. https://doi. org/10.1108/MD-07-2018-0821

Robertson Munro, F., \& Cairney, P. (2020). A systematic review of energy systems: The role of policymaking in sustainable transitions. Renewable and Sustainable Energy Reviews, 119. https://doi. org/10.1016/j.rser.2019.109598

Rosa, F., \& Prayitnoadi, R. P. (2020). Stress analysis of a rack gear on sea wave power plant design in Bangka Island. IOP Conference Series: Earth and Environmental Science, 599(1). https://doi.org/10.1088/17551315/599/1/012011

Rosyidi, M. I., Purwantini, A. H., Muliawanti, L., Purnomo, B. C., \& Widyanto, A. (2021). Communication Participation in Community Empowerment for Energy Independent Tourism Villages in the Pandemic Era (J. Prof., S. P., T. M.M., \& R. Z. (eds.); Vol. 232). EDP Sciences. https://doi.org/10.1051/ e3sconf/202123201036

Rueda, G., Gerdsri, P., \& Kocaoglu, D. F. (2007). Bibliometrics and social network analysis of the nanotechnology field. PICMET'07-2007 Portland International Conference on Management of Engineering \& Technology, 2905-2911.

Scarlat, N., Dallemand, J.-F., \& Fahl, F. (2018). Biogas: Developments and perspectives in Europe. Renewable Energy, 129, 457-472. https:// doi.org/10.1016/j.renene.2018.03.006

Schmidt, T. S., \& Sewerin, S. (2019). Measuring the temporal dynamics of policy mixes - An empirical analysis of renewable energy policy mixes' balance and design features in nine countries. Research Policy, 48(10). https://doi.org/10.1016/j. respol.2018.03.012
Setiawan, I. C., Indarto, \& Deendarlianto. (2019). System Dynamics Modeling of Indonesia Road Transportation Energy Demand and Scenario Analysis to achieve National Energy Policy Target. 546(5). https://doi. org/10.1088/1757-899X/546/5/052070

Setyowati, A. B. (2020). Mitigating energy poverty: Mobilizing climate finance to manage the energy trilemma in Indonesia. Sustainability (Switzerland), 12(4). https:// doi.org/10.3390/su12041603

Setyowati, A. B. (2021). Mitigating inequality with emissions? Exploring energy justice and financing transitions to low carbon energy in Indonesia. Energy Research and Social Science, 71. https://doi.org/10.1016/j. erss.2020.101817

Setyowati, H. A., Dwinugroho, M. P., Sigit Heru Murti, B. S., Yulianto, A., Ajiwihanto, N. E., Hadinata, J., \& Sanjiwana, A. K. (2018). ESDM One Map Indonesia Indonesia: Opportunities and Challenges to Support One Map Policy based on Applied Web-GIS. 165(1). https://doi.org/10.1088/17551315/165/1/012021

Silalahi, F. T. R., Simatupang, T. M., \& Siallagan, M. P. (2020). Biodiesel produced from palm oil in Indonesia: Current status and opportunities. AIMS Energy, 8(1), 81-101. https://doi.org/10.3934/energy.2020.1.81

Sinha, A., Shahbaz, M., \& Sengupta, T. (2018). Renewable energy policies and contradictions in causality: A case of Next 11 countries. Journal of Cleaner Production, 197, 73-84. https://doi.org/10.1016/j. jclepro.2018.06.219

Siregar, K., Tambunan, A. H., Sholihati, Wirawan, S. S., \& Araki, T. (2019). Comparison of energy production, net energy balance, net energy ratio, and renewable index for biodiesel production from oil palm (Elaeis guineensis Jacq.) and jatropha (Jatropha curcas L.) 
based on life cycle assessment (S. R.H. (ed.); Vol. 293, Issue 1). Institute of Physics Publishing. https://doi.org/10.1088/17551315/293/1/012025

Sommeng, A. N., \& Anditya, C. (2018). Boosting renewable power generation in Indonesia electricity sector: A policy action by the government (K. E., J. F.H., S. E.A., \& Y. A. (eds.); Vol. 67). EDP Sciences. https://doi. org/10.1051/e3sconf/20186702060

Sorda, G., Banse, M., \& Kemfert, C. (2010). An overview of biofuel policies across the world. Energy Policy, 38(11), 6977-6988. https:// doi.org/10.1016/j.enpol.2010.06.066

Stokes, L. C., \& Breetz, H. L. (2018). Politics in the U.S. energy transition: Case studies of solar, wind, biofuels and electric vehicles policy. Energy Policy, 113, 76-86. https://doi. org/10.1016/j.enpol.2017.10.057

Suharta, H., Soetrisnanto, A., \& Priyanto, U. (2017). Energy choice to support carbon dioxide reduction in Indonesia. In Mediterranean Green Buildings and Renewable Energy: Selected Papers from the World Renewable Energy Network's Med Green Forum (pp. 341-354). Springer International Publishing. https://doi.org/10.1007/9783-319-30746-6_24

Suhartini, S., Hidayat, N., \& Hadi, M. W. R. (2021). Co-digestion of cocoa pods and cocoa leaves: Effect of $\mathrm{C} / \mathrm{N}$ ratio to biogas and energy potential. IOP Conference Series: Earth and Environmental Science, 733(1). https://doi. org/10.1088/1755-1315/733/1/012139

Szinai, J. K., Sheppard, C. J. R., Abhyankar, N., \& Gopal, A. R. (2020). Reduced grid operating costs and renewable energy curtailment with electric vehicle charge management. Energy Policy, 136. https://doi.org/10.1016/j. enpol.2019.111051

Tanoto, Y., \& Praptiningsih, M. (2013). Factors decomposition of Indonesia's household electricity consumption. Engineering
Journal, 17(2), 19-28. https://doi. org/10.4186/ej.2013.17.2.19

Taqwa, A. (2019). Higher Education Role in Supporting Indonesian Government Policy in Developing Renewable Energy. 1167(1). https://doi.org/10.1088/17426596/1167/1/012010

Tsay, M., \& Shu, Z. (2011). Journal bibliometric analysis: a case study on the Journal of Documentation. Journal of Documentation. Vakulchuk, R., Overland, I., \& Scholten, D. (2020). Renewable energy and geopolitics: A review. Renewable and Sustainable Energy Reviews, 122. https://doi.org/10.1016/j. rser.2019.109547

Van Eck, N. J., \& Waltman, L. (2013). VOSviewer manual. Leiden: Univeristeit Leiden, 1(1), $1-53$.

Van Groenendaal, W. J. H. (2003). Group decision support for public policy planning. Information and Management, 40(5), 371-380. https://doi.org/10.1016/S03787206(02)00044-7

Wang, C.-N., Tibo, H., \& Duong, D. H. (2020). Renewable energy utilization analysis of highly and newly industrialized countries using an undesirable output model. Energies, 13(10). https://doi.org/10.3390/ en13102629

Wu, S., Alharthi, M., Yin, W., Abbas, Q., Shah, A. N., Ur Rahman, S., \& Khan, J. (2021). The carbon-neutral energy consumption and emission volatility: The causality analysis of asean region. Energies, 14(10). https:// doi.org/10.3390/en14102943

Yandri, E., Ariati, R., Uyun, A. S., Setyobudi, R. H., Anne, O., Susanto, H., \& Vincevica-Gaile, Z. (2020). Implementation of walk-through audits for designing energy management system: A first step towards an efficient campus (S. R.H. (ed.); Vol. 490, Issue 1). Institute of Physics Publishing. https://doi. org/10.1088/1755-1315/490/1/012005 
Ye, M., \& Li, H. (2020). Bibliometric Knowledge Mapping of e-commerce platform operation on data mining. 19. https://doi. org/10.20944/preprints202012.0529.v1

Yudha, H. M., Dewi, T., Risma, P., \& Oktarina, Y. (2018). Life Cycle Analysis for the Feasibility of Photovoltaic System Application in Indonesia. 2nd International Conference on Regional Science, Infrastructure Technology and Regional Development, ICoSITeR 2016, 124(1). https://doi.org/10.1088/17551315/124/1/012005

Yudha, S W, \& Tjahjono, B. (2019). Stakeholder mapping and analysis of the renewable energy industry in Indonesia. Energies, 12 (4). https://doi.org/10.3390/ en12040602

Yudha, S W, Tjahjono, B., \& Longhurst, P. (2021). Stakeholders' recount on the dynamics of indonesia's renewable energy sector. Energies, 14(10). https://doi.org/10.3390/ en 14102762

Yudha, Satya Widya, \& Tjahjono, B. (2019). Stakeholder Mapping and Analysis of the Renewable.1-19. https://doi.org/10.3390/ en12040602

Ziegler, M. S., Mueller, J. M., Pereira, G. D., Song, J., Ferrara, M., Chiang, Y.-M., \& Trancik, J. E. (2019). Storage Requirements and Costs of Shaping Renewable Energy Toward Grid Decarbonization. Joule, 3(9), 2134-2153. https://doi.org/10.1016/j. joule.2019.06.012

Zupic, I., \& Čater, T. (2015). Bibliometric methods in management and organization. Organizational Research Methods, 18(3), 429-472. 